\title{
Microbial Production of Value-added Products from Cashew Apples - An Economical Boost to Cashew Farmers
}

\author{
Vinoth Kannan ${ }^{1}$ D, Vivek Rangarajan ${ }^{1}$ (D) , Sampatrao D. Manjare ${ }^{1 *}$ (D) and \\ Pramod V. Pathak ${ }^{2}$ \\ ${ }^{1}$ Department of Chemical Engineering, Birla Institute of Technology and Science-Pilani, K.K. Birla Goa Campus, \\ Zuarinagar - 403 726, Goa, India. \\ ${ }^{2}$ Goa Energy Development Agency, State Govt of Goa, India.
}

\begin{abstract}
Cashew farming-considered as one of the major profit-making agricultural businesses- requires renewed practices in processing its products and by-products for sustained growth. The current review highlights the commercial potential of cashew apples by proposing value-addition strategies through microbial fermentation routes that can help garnering additional profit to the growers. The immense potential of cashew apples and pulp wastes generated after juice-extraction in producing a range of products through the fermentation process such as bioethanol, hydrolytic enzymes, lactic acid, biosurfactants, wine and Feni (an alcoholic beverage) is discussed. Furthermore, a case on the existing Feni-making practices in Goa, India is reviewed, and the need for upgrades in the processing methods for waste mitigation is emphasized. Based on the literature survey and from the gathered knowledge on cashew industries through visits to various cashew farming sites, it is strongly emphasized that a radical improvement in cashew farming is possible only through the adoption of holistic approaches in the cultivation and proper utilization of wastes and its management of cashew apples. Also, Feni production, which is the mainstay of India's current cashew processing industry, requires major up-gradation in processing methods to improve its quality, marketability, and export potential.
\end{abstract}

Keywords: Cashew apple, Fermentation, Feni, Mass balance, Waste utilization, Value-added products

\footnotetext{
*Correspondence: manjare@goa.bits-pilani.ac.in
}

(Received: June 24, 2021; accepted: September 24, 2021)

Citation: Kannan V, Rangarajan V, Manjare SD, Pathak PV. Microbial Production of Value-added Products from Cashew Apples - An Economical Boost to Cashew Farmers. J Pure Appl Microbiol. 2021;15(4):1816-1832. doi: 10.22207/JPAM.15.4.71

(C) The Author(s) 2021. Open Access. This article is distributed under the terms of the Creative Commons Attribution 4.0 International License which permits unrestricted use, sharing, distribution, and reproduction in any medium, provided you give appropriate credit to the original author(s) and the source, provide a link to the Creative Commons license, and indicate if changes were made. 


\section{INTRODUCTION}

Cashew (Anacardium occidentale L.) tree belongs to the family Anacardiaceae, which is native of Northeastern Brazil. The tree yields a soft fibrous fruit that yields juice, which is highly nutritious and contains an enormous amount of fermentable sugars, minerals, and vitamins. Several studies reported that cashew apple has three to six folds more Vitamin C than orange and ten times more than that of pineapple. ${ }^{1,2}$ Cashew, an essential commercial cash crop of India, is also considered as 'Gold mine' from the wastelands. While cashew nuts have found their way in a number of Indian cuisines, cashew apples are not even in the list of most likeable fruits owing to their readily perishable nature, susceptibility for quick fermentation, and presence of some phenolic compounds that imparts moderate astringency. However, presence of several compounds such as vitamin C, tannin, and polyphenol makes cashew apple rich in antioxidant properties. The detailed chemical and nutritional composition of the cashew apple is presented in Table 1.

\section{Significance of cashew apple}

Significance of cashew apples across the globe

Cashew tree, a tropical tree native of Brazil, was later introduced to Asia and Africa by European explorers in the sixteenth century. Now, it has spread across all the tropical countries. However, India, Brazil and a few other East African countries have been identified as the productive regions, where cashew cultivation is a primary occupation for a large section of farmers in the waste land zones. ${ }^{3}$ The major revenue earner from the cashew faming is cashew nut, as they are majorly exported to United States, Europe, and some Asian countries. ${ }^{4}$

The world production of cashew nuts reached 4.89 million tons in 2016, with Vietnam being the largest producer of nuts. Countries like India, Nigeria, and Brazil are the most significant producers. $^{5}$

\section{Significance of cashew apples in Indian Subcontinent}

In India, total cashew apple production was approximately 56 lakh MT. with about 2.32 lakh MT productions in Goa. While more than $80 \%$ of revenue comes from cashew nut sales, the yield and so the net profit in recent years has been on the decline owing to rapid change in the
Table 1. Chemical and nutritional composition of the cashew apple

\begin{tabular}{lcc}
\hline Constituents & $\begin{array}{c}\text { Amount } \\
\text { (per 100 g) }\end{array}$ & Ref. \\
\hline Moisture (\%) & 87.80 & \\
Protein (\%) & 0.20 & \\
Fat (\%) & 0.10 & \\
Crude fiber (\%) & 0.90 & \\
Carbohydrate (\%) & 11.60 & {$[44,45]$} \\
Phosphorous (mg) & 10 & \\
Iron (mg) & 0.2 & \\
Vitamin (mg) & 261 & \\
Minerals (mg) & 200 & \\
Calcium (mg) & 10 & \\
Thiamine (mg) & 0.02 & \\
Nicotinic acid (mg) & 0.4 & \\
Riboflavin (mg) & 0.5 & \\
Reducing sugar (\%w/v) & $9.04-10.04$ & {$[46,47]$} \\
Sucrose (\% w/v) & $0.0452-0.051$ & {$[48]$} \\
Fructose (\% w/v) & $3.90-4.52$ & {$[48]$} \\
Glucose (\% w/v) & $3.85-4.63$ & {$[49]$} \\
Tannins (mg) & 0.6 & \\
Tannins (mg) & 0.6 & {$[11]$} \\
Carotene (mg) & $0.03-0.74$ & \\
\hline
\end{tabular}

global weather pattern. Many cashew farmers are facing problems in disposing of a massive amount of wastes such as cashew apple, pulp, cashew shell nut oil, and cashew shell generated during cashew processing. ${ }^{6}$ Therefore, it is a significant national loss. However, in India, Goa is the only state where cashew apples are being thoroughly utilized for making alcoholic beverage "Feni," and it has been given Geographical Indication $(\mathrm{GI})^{7}$ for "Feni" production from cashew apple juice through spontaneous fermentation carried out by wild yeast. ${ }^{8}$ As per the rough estimates, 2240 $\mathrm{kg}$ of cashew apples yields about 117 litres of Feni per acre of cashew plantation. ${ }^{9}$ This prompted cashew farmers to consider all inclusive use of all types of wastes from cashew processing industries to create value-added products and further to upgrade their existing small-scale Feni production units to improve overall yield and quality of Feni. An Overview of emerging applications of cashew apple

Although cashew nuts are the major revenue earner for the cashew farmers, the cashew fruits as such do not have any economic value. However, a number of research works 


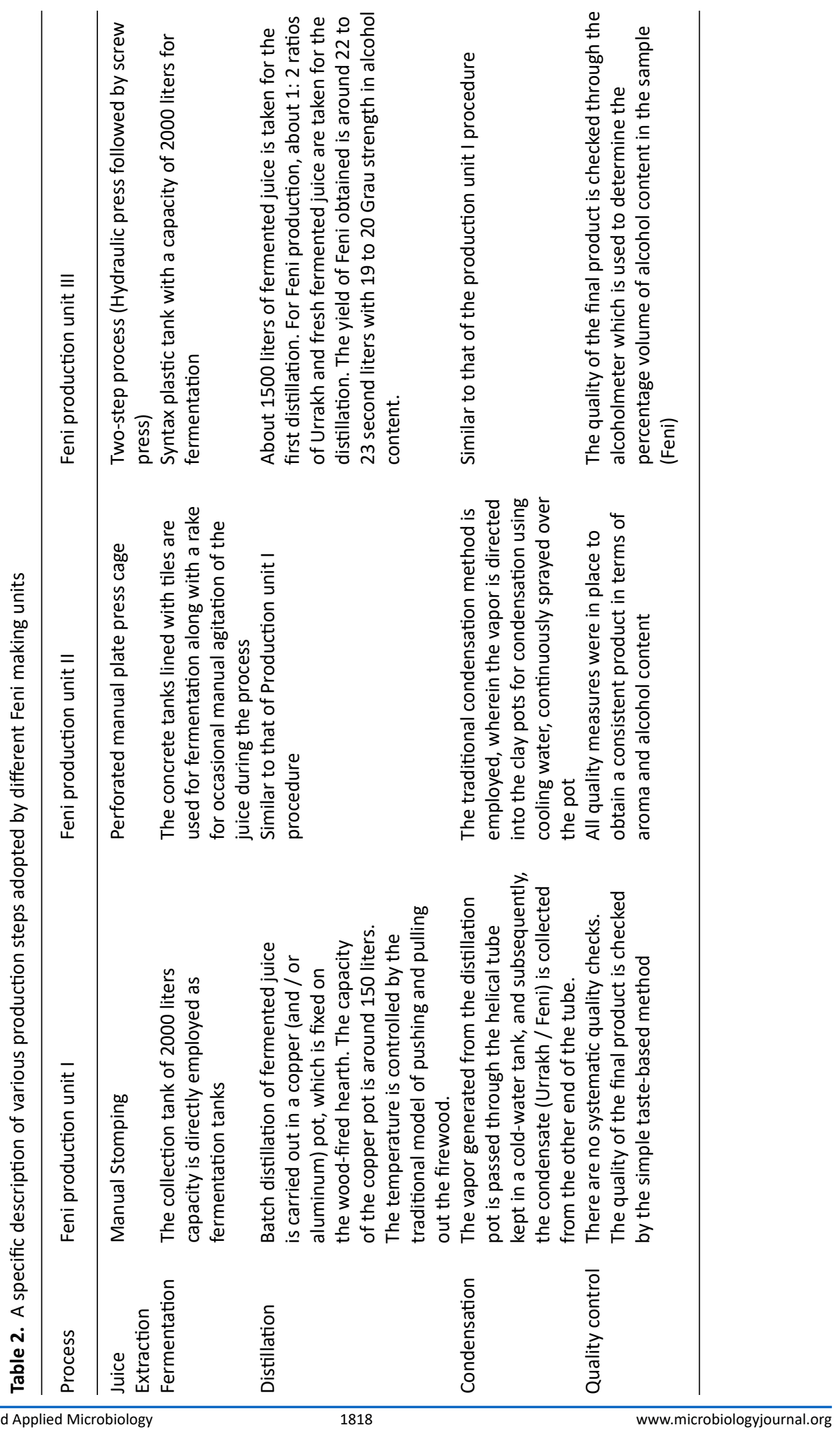


highlight the growing demand of cashew apple for various emerging applications as presented in Table A (Supplementary Information). While the majority of products from cashew apple are obtained via a fermentation process, there are a few value-added end products such as organic fertilizer, food products like jams, jellies, pickles, energy drinks, and cookies which directly utilize fruit juice or pulp for manufacturing. Various fermentation products that have been reported from cashew apple include bio-surfactant, alcohols, esters, etc.

The cashew apple waste can be converted to organic fertilizer via vermin-composting and has potential for manufacture of active carbon for various applications. For efficient fermentation of Cashew apples are subjected to various pretreatment procedures.

Pre-treatment of cashew apples before fermentation process

Before juice extraction, cashew apples are decontaminated by washing in 100 ppm chlorine water for the removal of contaminating microbes. ${ }^{10}$ The juice once extracted from the cashew apple is subjected to other pre-treatment procedures to make it free from unwanted components such as tannins and pectins that may affect the quality of juice.

Tannins belong to a group of phenolic compounds which can form active complexes with proteins and other macromolecules that can significantly affect the quality and aroma of Feni. Studies indicate the presence of $0.6 \mathrm{mg}$ tannins / $100 \mathrm{~g}$ of cashew apple juice. ${ }^{11}$ Tannins, owing to their ability to form complex with salivary protein and glycoprotein, impart a slight acidic taste to the fruit. ${ }^{12}$ Tannins can be removed by the addition of proteins (e.g., gelatin) or starch (e.g., sago, cassava starch) to the juice followed by filtration or siphoning.

Studies reported that the addition of enzymes such as pectinase could improve the yield of extraction and clarification of cashew apple juice..$^{13}$ Pectinase is a group of enzymes that are composed of pectin lyase, pectinesterase, and polygalacturonase. During the fermentation process, pectinesterase is the one that degrades the pectin and releases methanol into the products. The commercially available pectinase, such as Rapidase ADEX-D (100 g/ton), which is produced from Aspergillus spp., is especially developed for juice extraction.

Products from fermented cashew apple juice

As shown in Table 1, cashew apple is rich in nutrients such as carbon source and other important minerals that are required for fermentative production of some valuable products as discussed below.

\section{Tannase}

Tannase or tannin acyl hydrolase (EC. 3.1.1.20) is an enzyme, which catalyses the hydrolysis reaction of hydrolyzable tannin and gallic acid esters. The production of tannase from cashew apple bagasse was carried outin solid-state fermentation of Aspergillus oryzae. The production condition required a moisture content of $40 \%$. Tannase activity was detectable when the pulp contained tannin of $0.64 \mathrm{mg} / 100 \mathrm{~g}$ of pulp. ${ }^{14}$

In another work, tannase activity was increased by supplementing the cashew apple bagasse with sucrose and starch. ${ }^{15}$ However, the tannase production was lower cashew apple bagasse than other tested agro-wastes such as palm kernel cake, tamarin seed, Jamun leaves, and wheat bran (Table B/ Supplementary Information). Pectinase

Pectinase is a group of enzymes that catalyze the reaction for the degradation of pectic substances. Pectinases have various uses in the food industry, such as fruit juice clarification, juice extraction, and oil and treatment of wastewater. ${ }^{13}$

Pectinesterase, a type of pectinaseswas produced through solid-state fermentation of pectin-rich cashew apple waste by Aspergillus spp, Solid state fermentation required supplementation of additional nitrogen sources such as urea (15\%) and ammonium sulphate (5\%) of waste mass for improving growth of fungi in cashew apple bagasse. The highest pectinesterase activity of $0.29 \mathrm{U} / \mathrm{mg}$ was achieved at $40^{\circ} \mathrm{C}$ and after 8 days of incubation. ${ }^{16}$

\section{Eco-friendly surface-active compounds}

Bio-surfactants are surface active compounds produced by microorganisms. They have ability to reduce the surface tension and interfacial tension between liquid phases. Biosurfactants can be economically produced by using inexpensive substrates. Cashew apple juice was used as the substrate for the production of rhamnolipid from Pseudomonas spp. ${ }^{17}$ 
Kannan et al. | J Pure Appl Microbiol | 15(4):1816-1832 | December 2021 | https://doi.org/10.22207/JPAM.15.4.71

Table 3. Actual and theoretical mass balance of Feni production

\begin{tabular}{|c|c|c|c|c|c|}
\hline \multirow[t]{2}{*}{ Process } & & \multicolumn{2}{|c|}{ Actual Balance } & \multicolumn{2}{|c|}{ Theoretical balance } \\
\hline & & Input, kg & Output, Kg & Input, kg & Output, kg \\
\hline \multirow{5}{*}{$\begin{array}{l}\text { Juice } \\
\text { extraction }\end{array}$} & Overall feed & 1000 (fruit) & 700 (juice) & 1000 (fruit) & 750 (juice) \\
\hline & & & $300 \mathrm{Wp}$ & & \\
\hline & Sugar & 112.5 & 105 juice & $112.5 \mathrm{~kg}$ & 112.kg in juice \\
\hline & & & $7.25 \mathrm{~kg}$ in $W p$ & & \\
\hline & Alcohol & 0 & 0 & 0 & 0 \\
\hline \multirow[t]{3}{*}{ Fermentation } & Overall feed & 700 (Juice) & 686 (FJ) & 750 (FJ) & 750 (FJ) \\
\hline & Sugar & 105 & 10.5 & 112.5 & 0 \\
\hline & Alcohol & 0 & 47.3 & 0 & 57.375 \\
\hline \multirow[t]{4}{*}{ Distillation 1} & Overall feed & 686 (FJ) & 137.2 (Urrakh) & 750 (FJ) & 239 (Urrakh) \\
\hline & Sugar & 10.5 & 10.5 & 0 & 0 \\
\hline & Alcohol & 47.3 (FJ) & 32.928 (Urrakh) & 57.375 & 57.375 \\
\hline & & & 14.372 (Reboiler) & & \\
\hline \multirow[t]{6}{*}{ Distillation 2} & Overall feed & 137.2 & 124.52 (Feni) & 239 & 310.67 (Feni) \\
\hline & & (Urrakh) + & & (Urrakh)+ & \\
\hline & & 548.8 (* FJ) & & $956 \mathrm{~kg}(* * \mathrm{FJ})$ & \\
\hline & Sugar & 52.5 & 52.5 & 0 & 0 \\
\hline & Alcohol & 70.71 & 52.298 (Feni) & 130.87 & 130.87 \\
\hline & & & 18.412 (Reboiler) & & \\
\hline \multicolumn{6}{|c|}{ Fermentation Parameters } \\
\hline \multicolumn{2}{|c|}{ Yield (Yps) } & $0.282 \mathrm{~kg} / \mathrm{kg}$ & & & $0.51 \mathrm{~kg} / \mathrm{kg}$ \\
\hline \multicolumn{2}{|c|}{ Concentration } & $42 \mathrm{~g} / \mathrm{L}$ & & & $76 \mathrm{~g} / \mathrm{L}$ \\
\hline \multicolumn{2}{|c|}{ Productivity (48 hrs) } & $0.875 \mathrm{~g} / \mathrm{l} / \mathrm{h}$ & & & $1.58 \mathrm{~g} / \mathrm{l} / \mathrm{h}$ \\
\hline
\end{tabular}

*Indicates the actual quantity of fermented juice added during the distillation 2 to enrich the Feni aroma. ${ }^{* *}$ indicates the theoretical requirement of fermented juice added during the distillation 2 .

Wp- Wet pulp, Dp- Dry pulp, FJ- fermented juice.

Studies reported a significant reduction in surface tension from 50 dyne/cm to 29.5 dyne/cm when cashew apple juice was supplemented with $5 \mathrm{~g} / \mathrm{L}$ peptone. ${ }^{11,18}$ The rhamnolipid production was maximum $3.86 \mathrm{~g} / \mathrm{L}$ under optimal processing conditions at $30^{\circ} \mathrm{C}$ for $48 \mathrm{~h}$.

Emulsan is another type of bio-surfactant comprising of a sugar backbone linked with fatty acid. ${ }^{19}$ A. calcoaceticus RAG- 1 in the presence of cashew apple juice showed an emulsifying activity with kerosene $58.8 \%$ after $34 \mathrm{~h}$ of fermentation, while the surface tension was decreased only by about $17 \% .{ }^{18}$ Thus, emulsifier can be said as a better emulsifier than a surface tension reducing agent.

Studies also reported that surfactin (a lipopeptide type bio-surfactant) can be produced from cashew apple juice by various strains of $B$. subtilis. The strain $B$. subtilis inoculated in clarified cashew apple juice could result in a surfactin concentration of $3.5 \mathrm{~g} / \mathrm{L}$ after $24 \mathrm{~h}$ fermentation..$^{20}$

\section{Lactic acid}

A diluted cashew apple juice was employed for the production of lactic acid from Lactobacillus casei NRRL B-442. It was observed that higher the concentration of reducing sugar higher was the productivity of lactic acid, until the concentration of reducing sugar reached $60 \mathrm{~g} / \mathrm{L}$. A supplementation of $6 \mathrm{~g} / \mathrm{L}$ of ammonium sulfate ( $12 \% \mathrm{w} / \mathrm{w}$ of nitrogen/carbon ratio), at optimal conditions of $\mathrm{pH}=6.5$ and temperature $=37^{\circ} \mathrm{C}$ improved the lactic acid yield by about $95 \%$ with a productivity of $2.3 \mathrm{~g} /$ L.h. ${ }^{21-23}$

\section{Production of wine and bioethanol from cashew} apple

In one approach of wine making from the cashew apple, the initial sugar concentration was increased to above $20 \%(\mathrm{w} / \mathrm{v}$ ) by adding sucrose. The inoculum size of yeast also played an important role in fermentation process- inoculum volume in the range of about $0.1 \%$ to $12 \%$ was preferable. ${ }^{24,25}$ In general, lower ambient temperatures resultin a 
longer fermentation time, but a good aroma due to preservation of ester compounds. ${ }^{26,27}$ Under optimal ambient temperature, the final ethanol concentration in the wine was in the range of $5 \%$ to $12 \% .{ }^{10,25,28}$ The processing conditions and final ethanol concentration of cashew apple wine and bioethanol are shown in Table C (Supplementary Information).

Owing to the perishability of fresh cashew apples, the use of dried cashew apples was also practiced for wine production. Cashew apples can be sundried, mashed and made to powder form for long-term use. To prepare "MUST" (MUST is the freshly crushed grape juice which contains the skins, seeds and stems of the fruit for wine preparation) the powder is usually mixed with water, to achieve an initial solid content of $20 \%$. This method resulted in an alcohol content in wine of about $7 \%(\mathrm{v} / \mathrm{v})$, which was found to be lower than wine made from fresh cashew apple juice $(9.2 \% \mathrm{v} / \mathrm{v})$. However, wine made from cashew apple powder had a characteristic brown color, with appreciable sensory attributes, which were comparable to wine made from cashew apple juice. $^{25}$
For bioethanol production, the residual cashew apple pulp, also termed as bagasse was employed. This bagasse contains about $19-24 \%$ of cellulose, $12 \%$ of hemicellulose, and $22-38 \%$ of lignin on a dry basis. ${ }^{29,30}$ The bagasse needs to be pre-treated first in order to render it usable for further saccharification process, usually done by enzymatic process or by thermos-chemical methods. Pre-treatment with alkali/ acids removes lignin from cashew apple bagasse, whose presence otherwise would inhibit the fermentation process by inhibiting the growth of yeasts. In one of the works, pre-treatment of cashew apple bagasse in alkaline solution increased the bioavailability of cellulose for enzymatic hydrolysis. Upon enzymatic hydrolysis of pre-treated bagasse, a reducing sugar of $54 \mathrm{~g} / \mathrm{L}$ was achieved. Fermentation of the resulting hydrolysate resulted in a final ethanol concentration of $20 \mathrm{~g} / \mathrm{L}$ after $6 \mathrm{~h} .^{29}$

Cashew apple bagasse contained about $12 \%$ of hemicellulose. Xylose is the most abundant monomer unit of the hemicellulose. Since cashew bagasse also contained a good amount of hemicellulose comprising of pentose sugars such as xylose, yeast strains such as Pichia, Candida,

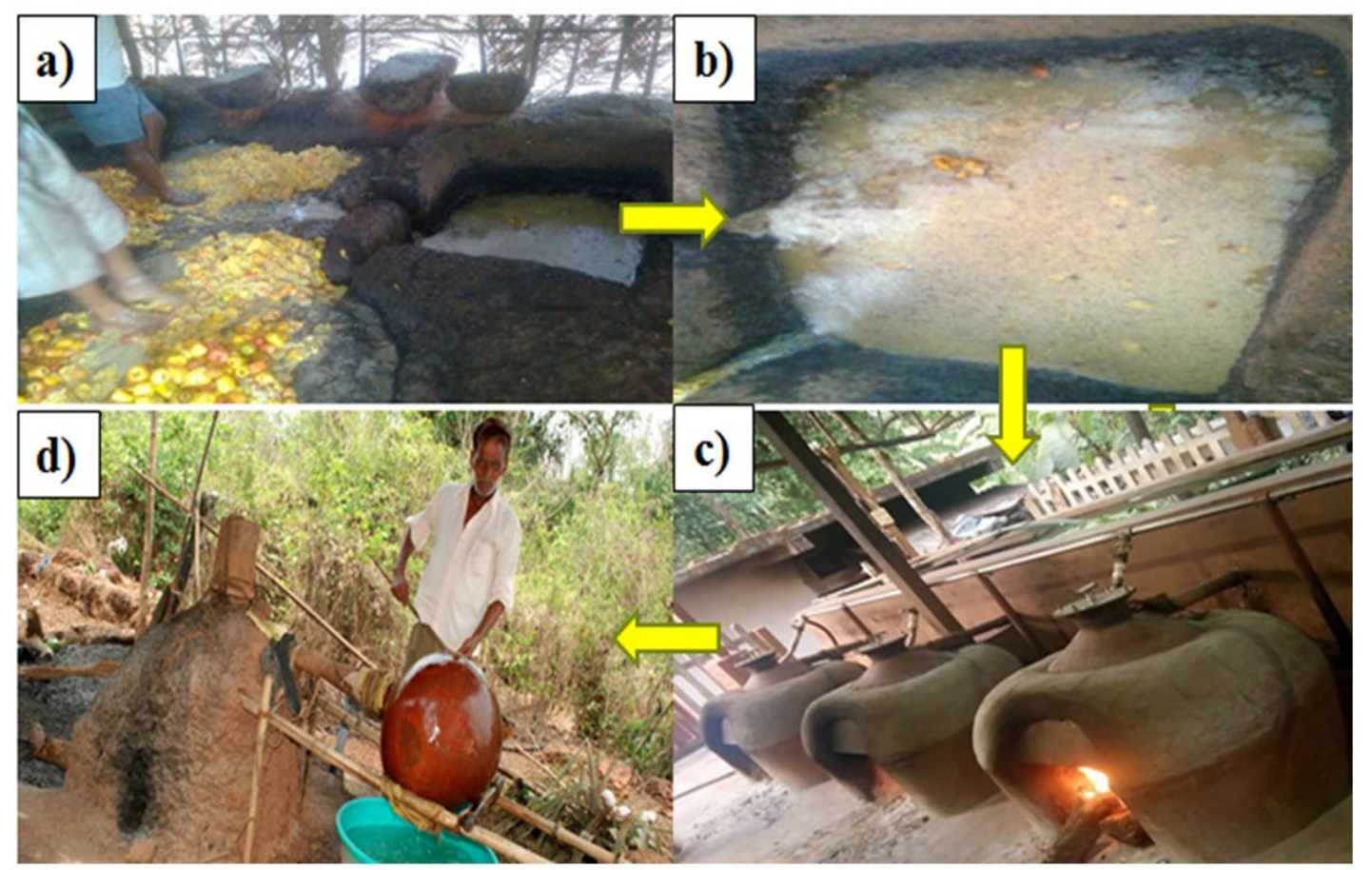

Fig. 1 (a-d). Traditional Feni making process. (a) Manual crushing (b) Juice collection tank (c) Distillation still (d) Distillate collection. 
and Kluyveromyces and genetically modified Saccharomyces cerevisiae can be employed for the production of ethanol from pentose sugars. ${ }^{31}$ Feni production Scenario in Goa

Feni-making Industry in Goa is mainly unorganized, scattered, and family-owned. The art of Feni-making has been passed on from generation to generation and is rich in the localized traditions. The conventional method of Feni making process is very simple and does not employ any standard manufacturing protocols, as shown in Fig 1. (a to d) (Supplementary Information).

The flow chart for the production of Feni making process is shown in Fig. 2 (graphical abstract). The ripened cashew apples are collected, and juice is extracted through the manually operated screw press method. Some Feni makers still follow the traditional stomping method for the extraction of cashew apple juice.

The obtained juice is collected in a collection tank, followed by pumping to the fermentation tank. It is allowed to stand for a period of 2 to 3 days. It undergoes natural fermentation. After fermentation, it is ready for the distillation. The Setup of distillation is traditionally called 'Bhati.' The fermented mixture is taken for first distillation in the copper cauldron. Two step distillation process is adopted for the final product called "Feni".

Wood-fired heaters are traditionally used for distillation. Temperature is controlled manually by pushing or withdrawing the quantity of the firewood. It is done based on the experience of the distiller (Bhatticar, as named in Konkani language). The juice starts boiling, and vaporization usually begins in about 45 minutes from the time of lighting of fire. The vapor passes through the stainless-steel (or copper in most cases) circular coil immersed in a cold-water tank. Vapors get condensed into a liquor called Urrakh. In the second stage distillation, Urrakh is taken along with fresh fermented cashew juice in the aluminum cauldron, and this mixture is again heated. This process gives the cashew Feni, which contains 42 to $43 \% \mathrm{v} / \mathrm{v}$ of alcohol content with its distinctive flavor and peculiar taste, not to be found in other liquors. ${ }^{8}$

The aroma is a valuable property that gives Feni drink a unique flavor. This aroma mainly results from the presence of volatiles in cashew apple. Studies reported that 71 volatiles are identified in cashew apple juice, ${ }^{32}$ of which 47 are odor-active (Table D/ Supplementary Information). They provide the fruity/cashew-like

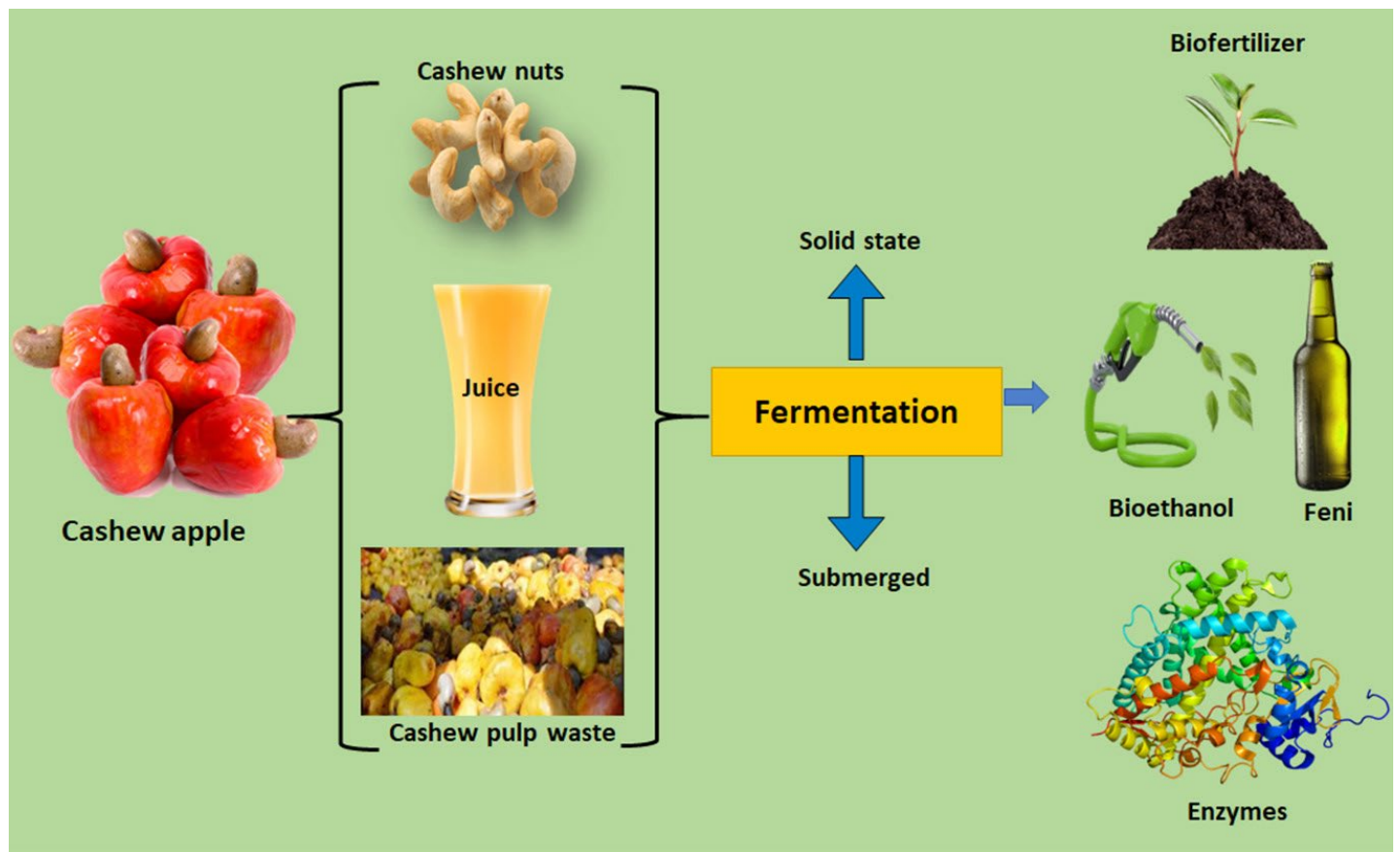

Fig. 2. Graphical Abstract 
smell to the water phase. Researchers reported that GC-MS analysis of a Brazilian cashew apple variety revealed numerous volatiles such as esters, terpenes, hydrocarbons, carboxylic acids, aldehydes, alcohols, ketones, lactones and norisoprenoids. ${ }^{33,34}$ It has been observed that the Feni drink usually bears the aroma of fruits, possibly by retaining some volatile aroma compounds after the distillation process. However, some of these volatile compounds may be altered during the fermentation process giving rise to new/ modified aroma fractions that provide a slightly different flavor to the Feni. Some of these more volatile aroma compounds might be lost due to partial condensation of vapor generated

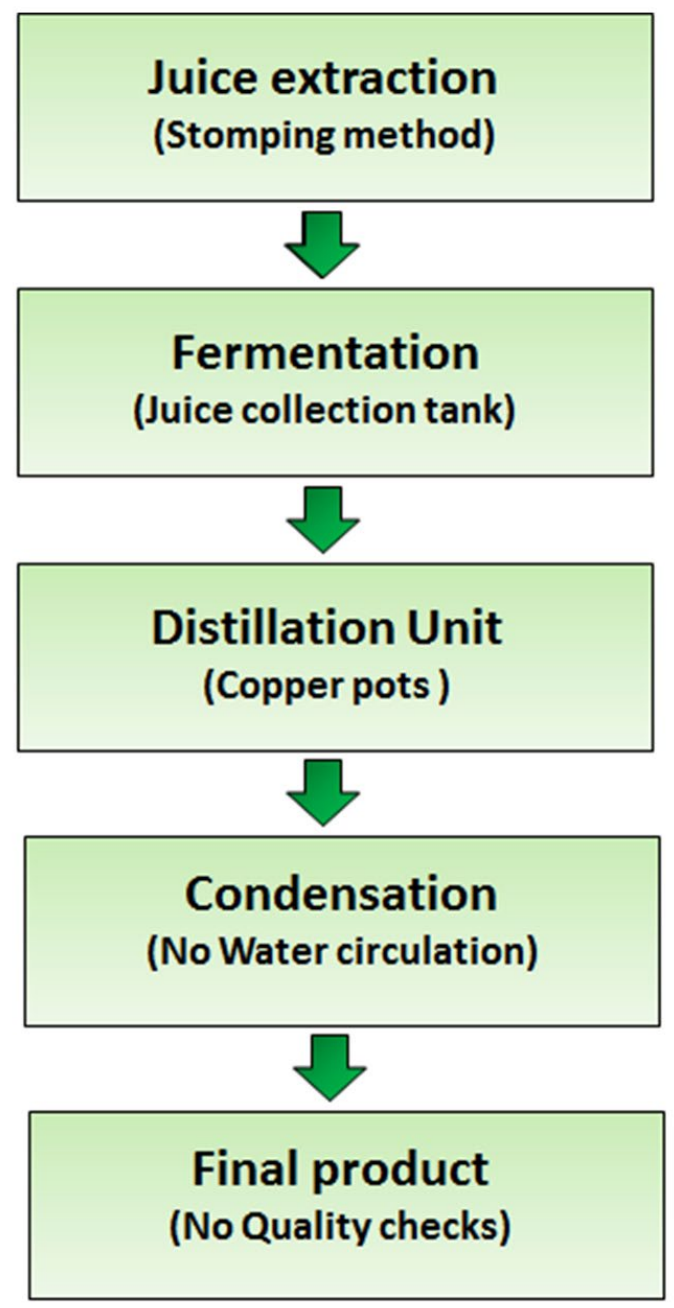

Fig. 3. Feni Production Process Involved in Production Unit-I. from the heating of fermented juice. Some of the high volatile aroma compounds may not be condensable to room temperature of cold water. Case study on Feni making

In Goa, cashew plantations are grown in large areas. Cashew plantation is mainly cultivated for cashew nut due to its economic significance and is a primary product. Conventionally, cashew apples have been utilized to prepare liquors by locals due to the abundance of its juicy nature. The current Feni production is highly traditional. Distillers are not adopting any standard manufacturing practices. Feni is a drink distilled from the fermented juice of cashew apples, and it is an integral part of Goan culture and is probably India's best-known local liquor. It has got medicinal properties, and consumption of it in low quantity

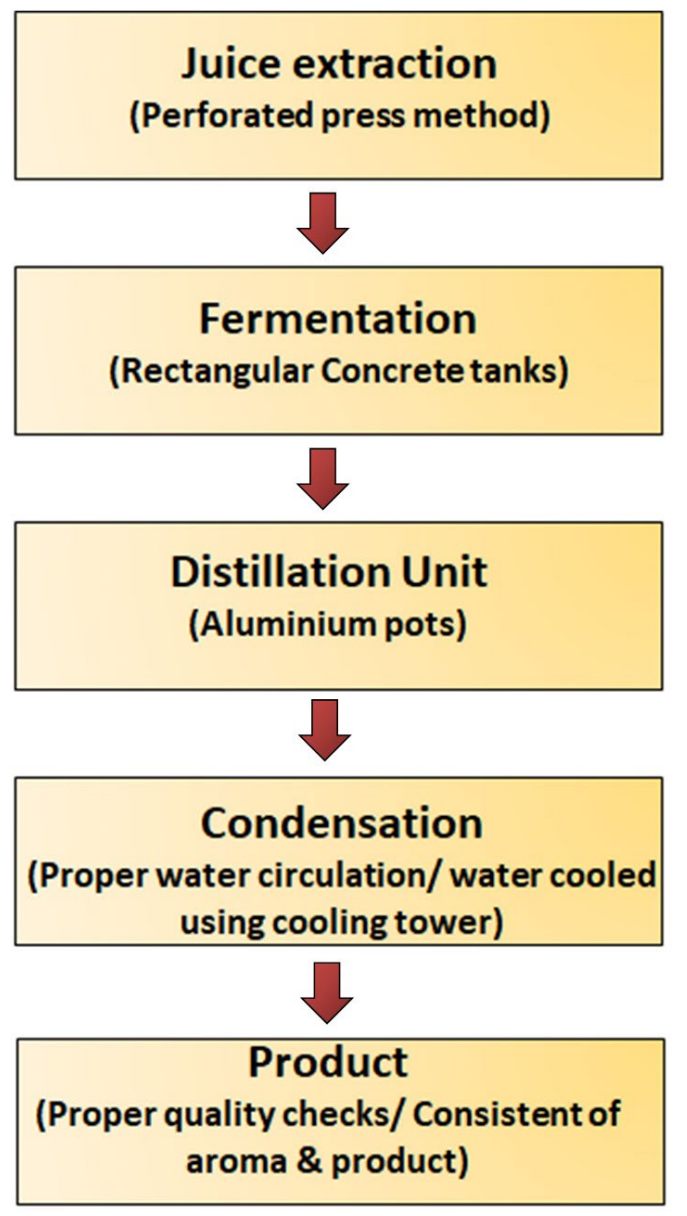

Fig. 4. Feni Production Process Involved in Production Unit-II. 
has been recommended by locals for relief from stomach problems, fever, and throat infections. After a number of visits to existing Feni production units in Goa, it has been observed that the Feni production methodology adopted by numerous micro-level production units scattered over the state is crude, mostly unorganized, and familyowned. Different production techniques result in subtle changes in Feni flavor due to changes in ester compositions. However, the overall aroma largely remains same, giving Feni a unique flavor. The product testing mechanisms also vary across the producers. It has been further observed that significant factors that contribute to loss in yield and consistency in Feni product quality are crude production techniques and variations in the type of yeast species used and initial reducing sugar concentrations.

The fermentation process is carried out by different uncontrolled and native microbial populations. The factors which are responsible for chemical changes in the formulation of cashew apple juice are a variety of cultivar, the region of cultivation, weather, farming practices, ripeness at harvest, and storing conditions. Studies reported that the presence of a diverse microbial population of yeast species varies from one region to another. Strains isolated from fermented cashew apple juice showed diversity among yeast species with Pichia as the predominant yeast genus. ${ }^{35}$ Ethanol production by yeast is one of the oldest industrial processes. The identification of the most potent yeast strain for use in industrial ethanol production primarily involves the assessment of yeast strain in terms of its ethanol tolerance, sugar tolerance, and invertase activity. One important reason for the screening of the yeasts for ethanol tolerance is that not all yeast strains that tolerate higher levels of ethanol are able to produce ethanol at desired concentrations. Studies revealed that yeast strains isolated from fermented cashew apple juice showed varied ethanol tolerance levels. ${ }^{32}$ The ethanol tolerance level of identified species was in the range of 6 to $10 \%$.

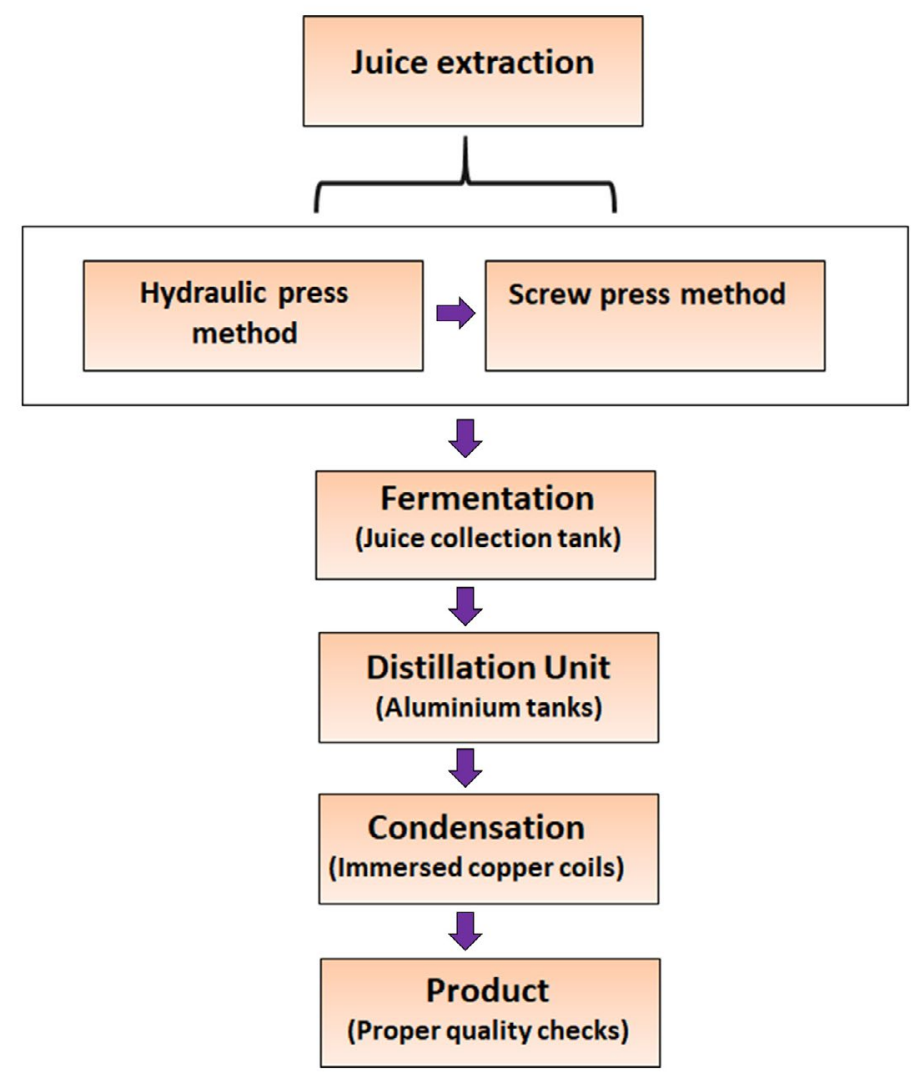

Fig. 5. Feni Production Process Involved in Production Unit-III 
As per the Bureau of Indian Standards (BSI) specifications for cashew Feni, it contains major aroma-based compounds and should be tested for these compounds (total and volatile acidity, esters, aldehydes, higher alcohols, alcohol and presence/absence of methanol). Different volatile compounds were seen in cashew apple, and it varied as per the methodology used or to different varieties of cultivars or geographical regions. ${ }^{36}$

\section{Various Processing stages involved in Feni} production

The various processes involved in the production of Feni include harvesting of the cashew fruits, extraction of juice, fermentation, and distillation. Each process is discussed in detail below.

\section{Harvesting}

The cashew fruit is handpicked to avoid damaging the delicate skin part of the fruit. The nuts are manually detached from the fruit and processed separately. Since cashew apples undergo rapid deterioration, they need to be processed within two to three hours of picking. The fruits are thoroughly washed and then immediately taken for juice extraction process.

\section{Extraction of juice}

The ripened cashew apples are collected, and juice is extracted through the screw press method. Some Feni makers follow the stomping method for the extraction of cashew apple juice. In the micro level units, cashew apples are generally crushed manually in a shallow tank to obtain the juice. While in large-scale, cashew apples are crushed through manual as well as motorized bench-press machines to obtain the juice.

\section{Fermentation}

The extracted juice is collected in collection tanks, followed by pumping to the fermentation tank or barrels, and it is allowed to stand for a period of 2 to 3 days for the natural fermentation process. The period of fermentation

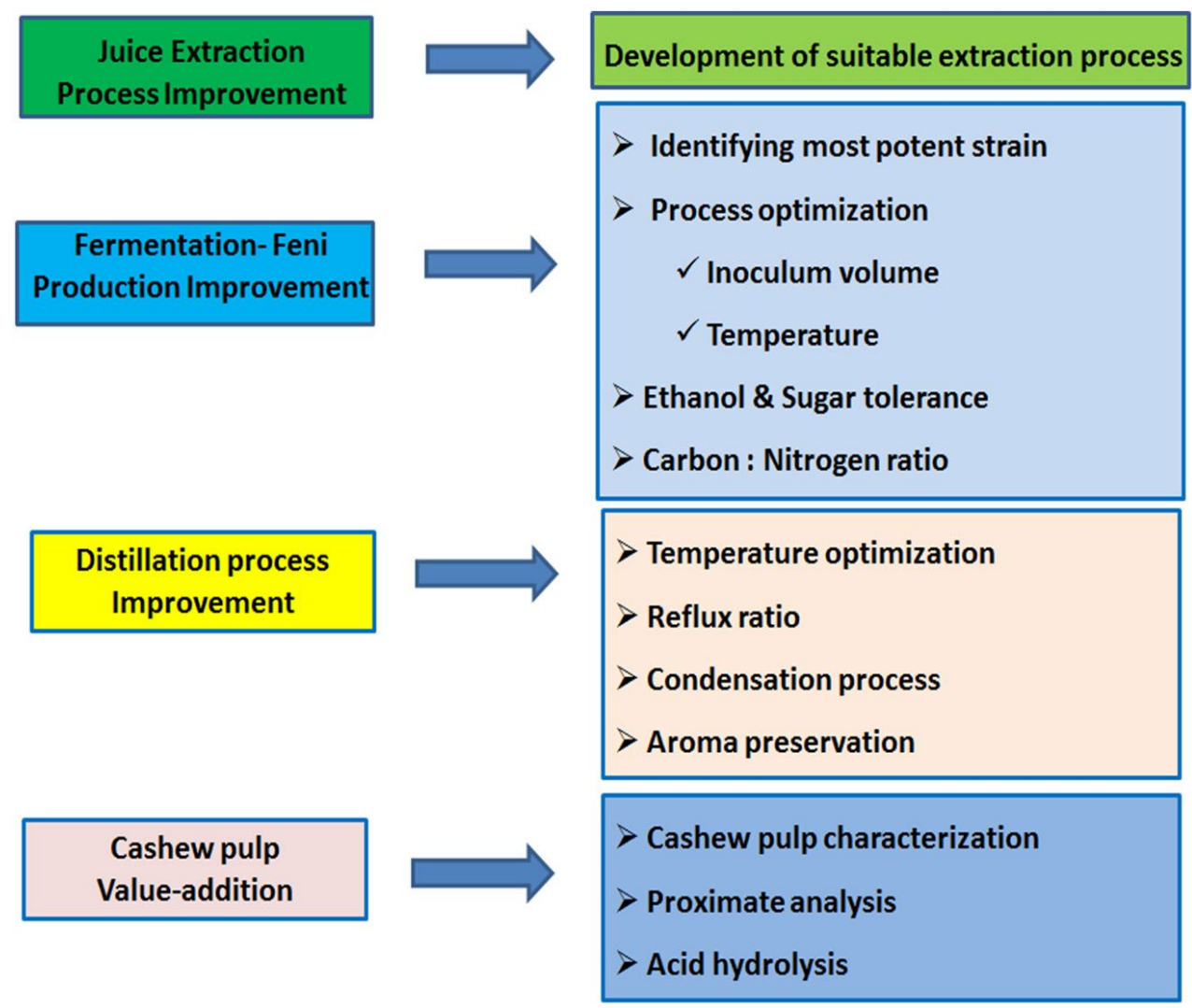

Fig. 6. Proposed process modifications for improved Feni production. 
is arbitrarily decided, but we observed that it was not allowed to exceed 3 days. After fermentation, juices are ready for the distillation process.

\section{Distillation}

The method of distillation traditionally is called 'Bhati.' The fermented juice mixture was taken for first distillation process in the aluminum (and / or Copper) cauldron and heated by the use of firewood. The juice starts boiling from the time of lighting the fire and the vapor passes through the stainless-steel (and / or Copper) circular coil immersed in a cold-water tank. Vapors get condensed into a liquor called Urrakh. For second distillation, Urrakh is taken along with fresh fermented cashew juice in the copper cauldron, and this mixture is again heated. Proportion of fresh juice with Urrakh from the first distillation is arbitrarily decided. The second stage distillation yields the cashew Feni, which contains 42 to $43 \%$ $\mathrm{v} / \mathrm{v}$ of alcohol content. ${ }^{8}$ The alcohol content is estimated through the Grau method or tastebased method. However, most of the Feni makers use the Grau method to estimate the alcohol content of both Urrakh and Feni. The Grau density is a measuring instrument that provides the level of alcohol concentration. The Grau measurement of the alcohol content varies from area to area and is dependent on the crushing method and the type of cashew apple being used.

This section of the paper investigates the various traditional practices adopted in Feni making units in Goa and further to understand the various aspects of Feni/Urrakh making by highlighting various challenges and scope for the overall process improvement. Authors of this review article visited a number of Feni making units in Goa to understand the art of Feni making process and to get further insight into the different strategies adopted as shown in Table 2.

In this review, production methods adopted by three Feni making units are highlighted. Among these, production unit III has incorporated improvised processing equipment at various stages of Feni making. The production unit II has employed improved version of juice extraction technique and cooling tower system with recirculation piping networks for the effective condensation of distillate. On the other hand, production unit I and other small-scale units still follow traditional practices such as stomping of fruits, use of clay pot (mudka) for fermentation and distillation, and rudimentary condensation setup for the enriched vapors. The standard practices adopted by some of these units are discussed below, and furthermore, their recent efforts towards the use of renewed processing strategies that can augment the overall production economy are also duly investigated and highlighted.

\section{Production unit I}

This production unit is located in North Goa, follows the conventional practice for Feni production, which has been used for generations. The flowsheet for the production of Feni from this unit $I$ is presented in Fig 3. The cashew apples are collected from the farms and transported to the distillery site, and the nuts are detached from the cashew apples. After removing the nuts, apples are stomped manually to extract the cashew apple juice.

The juice is subsequently transferred to collection tanks, each having a capacity of 2000 liters. Unlike other Feni making units where a separate tank was used for the fermentation process, the Production unit I employed the collection tanks as fermentation tanks. Fermentation is generally carried out for two to three days depending upon the ambient temperature to convert sugar into ethanol. As there are no other monitoring checks available to decide when to stop the fermentation, the Feni makers consider the cessation of froth as a simple thumb rule to harvest the fermented juice for further distillation.

\section{Distillation set up at production unit I}

The distillation of fermented juice is carried out in a copper pot with a layer of clay provided as insulation externally, and the pot is heated by firewood from the bottom using traditional Chula. However, there were no provisions made in the Chula for venting-off of the smoke and collection of ash, which is generally considered as retardant factors for heat transfer.

The vapor generated from the distillation potis passed through the helical tube-like structure, kept in a cold-water tank and subsequently the condensate (Urrakh / Feni) is collected from the other end of the tube. However, since the coolant water is not regularly replaced, it may lead to increased water temperature, thereby significantly affecting the condensation process and results in 
loss of ethanol yield. Also, there are no systematic quality checks that can ensure consistent aroma and yield of the product. The quality of the final product is checked by a simple tasting of samples to get a rough idea of the alcohol content and the endpoint of the distillation process.

\section{Production unit II}

Production unit II is located in North Goa.

This unit follows an almost similar procedure for Feni production to that of procedure adopted by production unit I except for the use of screw press for extraction of cashew apple juice. The flowsheet for the production of Feni from this unit-II is presented in Fig. 4. Included Standard manufacturing practice was adopted throughout the production process. For instance, the concrete fermentation tanks are lined with tiles, and a rake is provided for the manual agitation of the liquid juice during the fermentation process. Mechanical pumps are used for the transfer of fermented juice from the tank to the distillation units.

Distillation is carried out in a series of aluminum pots provided with the clay cladding for insulation. The traditional condensation method is employed, wherein the vapor is directed into clay pots for condensation using coolant water, which is sprayed continuously over the pot. An important feature to highlight is the use of a cooling tower, with a closed-loop coolant water recirculation system, which ensures the desirable, proper coolant water temperature for better heat exchange. All quality control measures were in place to obtain consistent Feni quality in terms of aroma and ethanol content.

\section{Production unit III}

Production unit III is located in North Goa. Here the authors observed the improved version of the Feni/Urrakh making process as compared to that of the traditional process as employed in production unit I and II.

The flow-sheet presented in Fig. 5 , included show the upgraded operations/ equipment in Feni making process at production unit III. For example, the following improvements are observed i) mechanical crushing instead of stomping ii) fermentation and distillation in steel/ aluminum tanks in place of clay pots iii) copper-coil based condensation system with the continuous feed of coolant water. In the production unit III, the alcohol content and aroma of Feni are regularly monitored to get a consistent quality of Feni.

- $\quad$ The juice is extracted from the harvested apples (as mentioned earlier) by a two-step extraction process comprising of manually operated screw cage press followed by hydraulic press. This two-step extraction process ensures maximum extraction efficiency.

- The cashew juice is pumped to the plastic syntax fermentation, and fermentation is carried out for 2 to 3 days, depending on the ambient temperature.

- The mud-chulas used for the distillation are provided with chimneys for proper venting of the exhaust gas, and provision is also made for the collection of ash.

Significant shortcomings in the existing Feni production practices and key suggestions to overcome

\section{Perspectives on Overall mass balance involved in Feni production}

From the process engineering point of view, mass balance at various stages helps identify the gaps in the existing stages and enables corrective measures to be implemented for the improvement in Feni production. Consequently, key parameters such as the mass of material fed into a process, conversion efficiency of a process, and overall yield of product obtained from the traditional process have to be quantified and compared with that of theoretical process parameters. In view of this, a case study on production unit III is undertaken to understand the overall aspects of mass balance in Feni production.

All relevant data needed for the calculation of yield and conversion efficiency at various stages were obtained from the realtime processes involved in production unit III. On average, the extracted cashew apple juice contains $15 \% \mathrm{w} / \mathrm{v}$ fermentable sugars. With these inputs and by assuming $100 \%$ efficiency for the conversion of sugar to alcohol (as shown below equation 1), it is estimated that $\mathrm{kg}$ of alcohol per batch would be produced.

$$
\mathrm{C}_{6} \mathrm{H}_{12} \mathrm{O}_{6} \longrightarrow 2 \mathrm{C}_{2} \mathrm{H}_{5} \mathrm{OH}+2 \mathrm{CO}_{2} \longrightarrow \text { (1) }
$$

Introducing approximations owing to mass transfer losses at various stages of processing results in the reduced yield of alcohol, estimated to be $52.83 \mathrm{~kg}$ of alcohol. Thus, the actual yield of alcohol from sugar is only $50 \%$ 
of the theoretical yield. The detailed actual and theoretical mass balance is presented in Table 3. Proposed process modifications for improved Feni production

From Table 3, it is noted that the actual yield of alcohol is $55 \%$ to that of the theoretical yield of alcohol. Also, the other parameters, such as concentration and productivity of alcohol, were significantly lower as compared to theoretical values. Thus, the poor alcohol yield obtained as determined through this case study signifies the need for process modification at various stages of Feni making. The various process interventions that need to be incorporated into the existing Feni production process are proposed in Fig. 6 . Included

The following are essential points that recommend modified or new processes/strategies that can augment improved Feni production:

\section{Juice Extraction}

- The juice extraction efficiency can be enhanced by adopting different pressing methods such as Hydraulic press followed by screw press or perforated press cage method instead of labor-intensive manual stomping. ${ }^{37}$.

- Extraction efficiency can be further enhanced by recycling a part of fresh cashew juice into the new batch of the cashew pulp that is fed into the extractor.

\section{Fermentation}

- The choice of yeasts plays an essential role in alcoholic fermentation. Therefore, the research on elucidating the diversity and identification of various potent yeast species present in the cashew apple juice and investigating their alcohol production capabilities can be useful. ${ }^{38} \mathrm{High}$ ethanol and sugar tolerance and optimal invertase activities are some of the desirable characteristics of a potent yeast strain. ${ }^{32}$

- Feeding the fresh juice with the culture of inoculum containing the potent alcohol producer can lead to the improved conversion of sugar, thereby increasing the yield and productivity of alcohol. However, the use of varying starter cultures of native yeasts should be avoided, as it resulted in considerable variation in chemical composition and concentration of the flavor compounds depending upon the metabolic activity of the yeast strain. ${ }^{39,40}$ By optimizing the quantity and age of inoculum culture, Feni with uniform consistency in terms of aroma and alcohol concentration, can be achieved.

- Temperature also plays an essential role in the fermentation process. In general, it has been observed that the incubation temperature determines the quality of aroma produced in the fermented fruit juice. For instance, the fermentation at lower temperatures preserved the aroma of Feni, by reducing the volatility of esters. Low temperature also reduced the formation of undesirable compounds as compared to fermentation at higher temperatures. ${ }^{41}$ However, this improved aroma quality is achieved at the expense of alcohol productivity, which results in a longer fermentation time.

- In any microbial fermentation process, the C: $\mathrm{N}$ ratio of the liquid medium that supports optimal growth of culture and product formation generally falls in the range of 10:1 to $20: 1$. The presence of low nitrogen content in the cashew apple juice signifies the need for the supplementation of additional nitrogen sources in the form of ammonia, which can improve the fermentation efficiency. ${ }^{23}$

- Monitoring and control of other process parameters such as $\mathrm{pH}$, agitation rate in conjunction with measurement of biomass growth and alcohol formation and maintaining the proper record should become an integral part of the production process to obtain the consistent quality of Feni.

- Use of steel tanks as fermentation vessels having provisions for feeding fresh juice and harvesting the fermentation broth is an essential step towards good manufacturing practice.

\section{Distillation}

In general, both traditional distillation and improved version of distillation setups are used by Feni producers. While the use of simple mudka earthen pots made of clay is widely prevalent among the traditional Feni makers, improved distillation designs are also seen in some units.

\section{For traditional Feni making units}

- Mud pots can be replaced with copper pots for improved thermal conductivity. (Mud pot processing is for imagined delicacy and very few are using it) 
- Adoption of improved chulas designs with provisions for venting exhaust gas and ash collection can minimize the fuel requirement and improve the overall heat transfer.

- Condensation can be improved by maintaining the coolant water temperature in the condensation tank by a continuous replacement of the coolant water. Use of cooling tower for water circulation will automatically control the temperature rise.

\section{For improved Feni making units}

- Installation of appropriate distillation column set up with all required accessories such as temperature indicators, liquid level indicator for reboiler, steam heated jacketed vessels with bottom discharge, semi-continuous feed input, can enhance the productivity of Feni.

- Monitoring and controlling of temperature and $\mathrm{pH}$ in the reboiler, followed by the use of optimal reflux ratio can lead to the production of the consistent quality of Feni with increased yield.

- Generally, it is observed that water at room temperature is used as a coolant medium in condensation operation. However, there are several low boilers such as esters and aldehyde present in the vapors from the reboiler, which escape uncondensed results in the loss of aroma and alcohol yield in the Feni production. Therefore, the use of coolant water at a lower temperature is recommended to improve the condensation operation and/or a volatile trap with coolant can help recover the volatiles.

\section{Cashew pulp value addition}

- About $70 \%$ of the total fruits are wasted as residual pulp which is currently disposed off without further processing/treatments in the adjacent land.

- Cashew apple waste can generate additional revenue to the cashew farmer if utilized properly. For instance, the residual pulp rich in carbohydrates, proteins, cellulose, hemicellulose, lignin and other minerals can act as a biomass feed stock for the production of products such as biofertilizer, bioethanol. . $^{2930,42}$

- If cashew fruits are processed under hygienic environment and with good manufacturing practices, the pulp can serve as a valuable raw material for food industry application. For example, the dietary fiber rich cashew pulp can be used as an alternative fiber additive in baking industry for making cookies and bread. ${ }^{25}$ This addition can improve the olfactory quality of the cookies. Apart from the production of alcoholic beverage, cashew fruits can be used for the preparation juice, health drinks, syrup, jam, jelly, candies and vinegar. ${ }^{43}$

\section{Conclusion \& future perspective}

Cashew farming once considered to be lucrative business is currently facing a number of challenges owing to climatic changes, poor agricultural practices and rapid urbanization. The sustainability of cashew farming largely depends on the willingness of farmers to adopt scientific approaches in their agricultural practices and food processing. An inclusive approach that capitalizes all bye-products of cashew farming such as cashew apple, pulp, cashew nutshell etc. in the making of value-added products which can bring additional revenue to the farmers. Thus, a paradigm shift in the cultivation, processing and marketing is the need of the hour for the sustainability of cashew farming industry.

While cashew nuts are the major revenue earner for the cashew farmers, the easily perishable cashew apples end up in making of alcohol. However, in India particularly Goa, the alcoholic beverage holds $\mathrm{GI}$ tag which is sold in the name "Feni". In Goa, there are number of small and unorganized Feni making units that make liquors of two different alcohol cuts namely Urrakh with $24 \%$ alcohol content and Feni with $42 \%$ alcohol content. Cashew apple wine and Feni contain unique aroma, differentiating it from alcoholic beverages produced from various other fruits. Although Feni has a good export value, many Feni making units owing to their poor manufacturing practices are not able to produce Feni of consistent quality that matches the export quality. So, a very few distillers who are able to adapt to modern processing methods hold major share in the Feni business.

From the holistic perspective, cashew apple can be considered as a feed stock for production of number of products. Due to the moderate concentration of the initial sugar content of cashew apple, the production of bioethanol may 
not be suitable compared to other raw materials. Cashew apple can act as a potential substrate for the enzyme production due to the presence of substrates such as lignocellulosic material, tannin, and pectin.

Presently, Goa is the only state in India where cashew-apple rejects are used to manufacture Feni. However, most of the Feni production units are adopting traditional practices for production of Feni which vary from unit to unit. As discussed earlier, there is a sufficient scope to standardize the Feni production practice thereby addressing the incumbent challenges ever face by the Feni makers. With this renewed Feni production practice, there is a good possibility for setting up export-oriented liquor making units in cashew growing areas, which will not only help the cashew growers to utilize the waste material but also generate more employment opportunities in rural areas.

In view of stringent environmental regulations and increased public awareness about environmental pollution it is important to estimate environmental impacts associated with production process of Feni product using Life cycle assessment (LCA). LCA study will estimate the environmental impacts associated with Feni production starting from cashew apple plantation to the production of value-added products from cashew apple pulp waste.

SUPPLEMENTARY INFORMATION
Supplementary information accompanies this
article at https://doi.org/10.22207/JPAM.15.4.71
Additional file: Additional Tables

\section{ACKNOWLEDGMENTS}

The authors are thankful to Department of Science and Technology (DST) Goa for providing the research funding. Authors acknowledge support from management of BITS Pilani K K Birla Goa campus during this project. The authors are grateful to all the Feni manufacturers who have provided all the necessary data and operations information.

\section{CONFLICT OF INTEREST}

The authors declare that there is no conflict of interest.

\section{AUTHORS' CONTRIBUTION}

SDM conceived this project. VK involved in literature study and wrote the draft manuscript. SDM and VR revised the manuscript and assisted with literature search. PVP contributed in the Field visit and provided operations information from Feni manufactures.

\section{FUNDING}

This work was funded by a research grant from Department of Science and Technology (DST) Goa (Grant No. 6-198-2016)

\section{DATA AVAILABILITY}

All datasets generated or analyzed during this study are included in the manuscript.

\section{ETHICS STATEMENT}

This article does not contain any studies with human participants or animals performed by any of the authors.

\section{REFERENCES}

1. Cavalcante AAM, Rubensam G, Erdtmann B, Brendel M, Henriques JAP. Cashew (Anacardium occidentale) apple juice lowers mutagenicity of aflatoxin B1 in $S$. typhimurium TA102. Genet Mol Biol. 2005;28(2):328333. doi: 10.1590/S1415-47572005000200025

2. Desai MV, Dubey KV, Vakil BV, Ranade VV. Isolation, identification and screening of the yeast flora from Indian cashew apple for sugar and ethanol tolerance. Int J Biotechnol Wellness Ind. 2012;1(4):259-265. doi: 10.6000/1927-3037.2012.01.04.6

3. Lorenzi A. Arvores brasileiras: manual de identificacao e cultivo de plantas arbo'reas nativas do Brazil, 4th ed. Instituto Plantarum, Nova Odessa, Fortaleza, Ceara, Brazil. 2004.

4. MELO FILHO, J.R.T. Fruticultura - Caju oferece emprego e renda nas longas estiagens. Gleba Magazine Newsletter, Oct. 2002. http://www.cna.org. br/Gleba02/Out/ArtigoCaju.html - Accessed on: March 18, 2019.

5. FAO. The Food and Agriculture Organization of United Nations. http://www.fao.org/statstics/en. 2018. Accessed on 1 Nov. 2018

6. Filgueiras HAC, Alves RE, Mosca JL, Menezes JB. Cashew apple for fresh consumption: Research on harvest and posthar vest technology in Brazil. Acta Hortic. 1999;485:155-160. doi: 10.17660/ ActaHortic.1999.485.20 
7. Rangnekar, Dwijen, Geographical Indications and Localisation: A case study of Feni (September 24, 2009). ESRC Report, 2009, Available at SSRN: https:// ssrn.com/abstract $=1564624$

8. Mandal RC, Dhandar DG, Dhume CV. Cashew Apple Liquor Industry in Goa. Acta Hortic. 1985;108:172-175. doi: 10.17660/ActaHortic.1985.108.32

9. Bhakta GD. FENI Industry in Goa: Prospects and Constraints. In: Proceedings and recommendation of State level Seminar on New Challenges in Cashew production under current trends of climate changes, ICAR, Goa, pp. 16-17. 2010.

10. Muir-Beckford M, Badrie N. Consumer acceptance of tropical wines from aloe vera (Aloe barbadensis) and cashew apples (Anacardium occidentale L.) in the British Virgin Islands. Food Res Int. 2000;12(3):185-196. doi: 10.1111/j.1745-4506.2000.tb00014.x

11. Rocha MVP, Souza MCM, Benedicto SCL, et al. Production of biosurfactant by Pseudomonas aeruginosa grown on cashew apple juice. Appl Biochem Biotechnol. 2007;137-140(1-12):185-194. doi: 10.1007/s12010-007-9050-6

12. Fontoin $\mathrm{H}$, Saucier $\mathrm{C}$, Teissedre PL, Glories $\mathrm{Y}$. Effect of $\mathrm{pH}$, ethanol and acidity on astringency and bitterness of grape seed tannin oligomers in model wine solution. Food Qual Prefer. 2008;19(3):286-291. doi: 10.1016/j. foodqual.2007.08.004

13. Gummadi NS, Manoj N, Kumar DS. Structural and biochemical properties of pectinases: structure, function and application. Ind Enzym. 2007:99-115. doi: 10.1007/1-4020-5377-0_7

14. Campos DCP, Santos AS, Wolkoff DB, Matta VM, Cabral LMC, Couri S. Cashew apple juice stabilization by microfiltration. Desalination. 2002;148(1-3):61-65. doi: 10.1016/S0011-9164(02)00654-9

15. Rodrigues THS, Pinto GAS, Goncalves LRB. Effects of inoculum concentration, temperature, and carbon sources on tannase production during solid state fermentation of cashew apple bagasse. Biotechnol Bioprocess Eng. 2008;13(5):571-576. doi: 10.1007/ s12257-008-0014-7

16. Silva D, Tokuioshi K, Da Silva Martins E, Da Silva $\mathrm{R}$, Gomes E. Production of pectinase by solidstate fermentation with Penicillium viridicatum RFC3. Process Biochem. 2005;40(8):2885-2889. doi: 10.1016/j.procbio.2005.01.008

17. Banat IM, Franzetti A, Gandolfi I, et al. Microbial biosurfactants production, applications and future potential. Appl Microbiol Biotechnol. 2010;87(2):427444. doi: 10.1007/s00253-010-2589-0

18. Rocha MVP, Oliveira AHS, Souza MCM, Goncalves LRB. Natural cashew apple juice as fermentation medium for biosurfactant production by Acinetobacter calcoaceticus. World J Microbiol Biotechnol. 2006;22(12):1295-1299. doi: 10.1007/s11274-0069175-8

19. Castro GR, Panilaitis B, Kaplan DL. Emulsan, a tailorable biopolymer for controlled release. Bioresour Technol. 2008;99(11):4566-4571. doi: 10.1016/j. biortech.2007.06.059

20. Rocha MVP, Barreto RVG, Melo VMM, Goncalves LRB. Evaluation of cashew apple juice for surfactin production by bacillus subtilis LAMI008. Appl Biochem Biotechnol. 2009b;155(1-3):366-378. doi: 10.1007/ s12010-008-8459-x

21. Guilherme AA, Silveira MS, Fontes CPML, Rodrigues S, Fernandes FAN. Modeling and Optimization of Lactic Acid Production using Cashew Apple Juice as Substrate. Food Bioprocess Technol. 2012;5(8):3151-3158. doi: 10.1007/s11947-011-0670-z

22. Silveira M, Fontes $\mathrm{C}$, Guilherme A, Fernandes F, Rodrigues $S$. Cashew apple juice as substrate for lactic acid production. Food Bioproc Tech. 2012;5(3):947953. doi: 10.1007/s11947-010-0382-9

23. Sivagurunathan $P$, Athisayakumar $P$, Uma $C$, Muthulakshmi K, Satheeshkumar S. Utilization of cashew apple juice as substrate for Lactic acid production. Int J. Res Stud Biosci 2018;6(4):1-6. doi: 10.20431/2349-0365.0604001

24. Sudheer Kumar Y, Prakasam RS, Reddy OVS. Optimisation of fermentation conditions for mango (Mangifera indica L.) wine production by employing response surface methodology. Int J Food Sci Technol. 2009;44(11):2320-2327. doi: 10.1111/j.13652621.2009.02076.x

25. Ogunjobi MAK, Ogunwolu SO. Physicochemical and Sensory Properties of Cassava Flour Biscuits Suplemented with Cashew Apple Powder. J Food Technol. 2010;8(1):24-29. doi: 10.3923/ jftech.2010.24.29

26. Garruti DS, Franco MRB, Da Silva MAAP, Janzantti NS, Alves GL. Assessment of aroma impact compounds in a cashew apple-based alcoholic beverage by GCMS and GC-olfactometry. LWT - Food Sci Technol. 2006;39(4):373-378. doi: 10.1016/j.Iwt.2005.02.006

27. Molina AM, Swiegers JH, Varela C, Pretorius IS, Agosin $E$. Influence of wine fermentation temperature on the synthesis of yeast-derived volatile aroma compounds. Appl Microbiol Biotechnol. 2007;77(3):675-687. doi: 10.1007/s00253-007-1194-3

28. Attri BL. Effect of initial sugar concentration on the physico-chemical characteristics and sensory qualities of cashew apple wine. Indian J Nat Prod Resour. 2009;8(4):374-379.

29. Rocha MVP, Rodrigues THS, De MacEdo GR, Goncalves LRB. Enzymatic hydrolysis and fermentation of pretreated cashew apple bagasse with alkali and diluted sulfuric acid for bioethanol production. Appl Biochem Biotechnol. 2009a;155(1-3):407-417. doi: 10.1007/s12010-008-8432-8

30. Rodrigues THS, Rocha MVP, De MacEdo GR, Goncalves LRB. Ethanol production from cashew apple bagasse: Improvement of enzymatic hydrolysis by microwaveassisted alkali pretreatment. Appl Biochem Biotechnol. 2011;164(6):929-943. doi: 10.1007/s12010-011-91853

31. Rocha MVP, Rodrigues THS, Melo VMM, Goncalves LRB, MacEdo GR De. Cashew apple bagasse as a source of sugars for ethanol production by Kluyveromyces marxianus CE025. J Ind Microbiol Biotechnol. 2011;38(8):1099-1107. doi: 10.1007/s10295-0100889-0

32. Sampaio KL, Garruti DS, Franco MRB, Janzantti NS, da Silva MAAP. Aroma volatiles recovered in the water 
phase of cashew apple (Anacardium occidentale L.) juice during concentration. J Sci Food Agric. 2011;91(10):1801-1809. doi: 10.1002/jsfa.4385

33. Bicalho B, Pereira AS, Aquino Neto FR, Pinto AC, Rezende CM. Application of high-temperature gas chromatography-mass spectrometry to the investigation of glycosidically bound components related to cashew apple (Anacardium occidentale L. var. nanum) Volatiles. J Agric Food Chem. 2000;48(4):11671174. doi: 10.1021/jf9909252

34. Bicalho B, Rezende CM. Volatile compounds of cashew apple (Anacardium occidentale L.). Zeitschrift fur Naturforsch - Sect C J Biosci. 2001;56(1-2):35-39. doi: 10.1515/znc-2001-1-206

35. Barbuddhe SB, Desai AR, Doijad SP, Singh NP. Diversity of yeasts isolated from fermented products. In: Microbial diversity and its applications, New India Publishing Agency, New Delhi. 2013.

36. Franco MRB, Janzantti NS. Aroma of minor tropical fruits. Flavour Fragr J. 2005;20(4):358-371. doi: 10.1002/ffj.1515

37. Wilczynski K, Kobus Z, Dziki D. Effect of press construction on yield and quality of apple juice. Sustain. 2019;11(13):3630. doi: 10.3390/su11133630

38. Pretorius IS. Tailouring wine yeasts for the new millennium: novel approaches to the ancient art of winemaking. Yeast. 2000;16(8):675-729. doi: 10.1002/1097-0061(20000615)16:8<675::AIDYEA585>3.0.CO;2-B

39. Lambrechts MG, Pretorius IS. Yeast and its Importance to Wine Aroma. S. Afr. J.Enol.Vitic. 2000;21:97-129. doi: 10.21548/21-1-3560

40. Romano P, Fiore C, Paraggio M, Caruso M, Capece A. Function of yeast species and strains in wine flavour. Int J Food Microbiol. 2003;86(1-2):169-180. doi: 10.1016/ S0168-1605(03)00290-3

41. Garruti DS, de Abreu FAP, Franco MRB, da Silva MAAP. The influence of fermentation temperature and sulfur dioxide on the volatile composition and flavour profile of cashew wine. Dev Food Sci. 2006a;43:109-112. doi: 10.1016/S0167-4501(06)80026-9

42. Rale VB. Production of feed yeast and yeastenriched livestock feed from cashew apple. MIRCEN J Appl Microbiol Biotechnol. 1985;1(3):205-212. doi: 10.1007/BF01742315

43. Suganya P, Dharshini R. Value added products from cashew apple - an alternate nutritional source. Int J Curr Res. 2011;3(7):177-180.

44. Akinwale TO. Cashew apple juice: Its use in fortifying the nutritional quality of some tropical fruits. Eur Food Res Technol. 2000;211(3):205-207. doi: 10.1007/ s002170050024

45. Costa JMC Da, Felipe EMDF, Maia GA, Hernandez FFF, Brasil IM. Production and characterization of the cashew apple (Anacardium Occidentale L.) and guava (Psidium Guajava L.) fruit powders. J Food Process Preserv. 2009;33(Suppl. 1):299-312. doi: 10.1111/j.1745-4549.2008.00342.x

46. Oduwole OO, Akinwale TO, Olubamiwa O. Economic evaluation of a locally fabricated extraction machine for a cottage cashew juice factory. J Food Technol
Africa. 2001;6(1):18-20. doi: 10.4314/jfta.v6i1.19278

47. Honorato TL, Rabelo MC, Goncalves LRB, Pinto GAS, Rodrigues S. Fermentation of cashew apple juice to produce high added value products. World J Microbiol Biotechnol. 2007;23(10):1409-1415. doi: 10.1007/ s11274-007-9381-z

48. Azevedo DCS, Rodrigues A. Obtainment of high-fructose solutions from cashew (Anacardium occidentale) apple juice by simulated moving-bed chromatography. Sep Sci Technol. 2000;35(16):2561-2581. doi: 10.1081/ SS-100102356

49. Honorato TL, Rodrigues S. Dextransucrase stability in cashew apple juice. Food Bioprocess Technol. 2010;3(1):105-110. doi: 10.1007/s11947-008-0053-2 50. Fontes CPML, Honorato TL, Rabelo MC, Rodrigues S. Kinetic study of mannitol production using cashew apple juice as substrate. Bioprocess Biosyst Eng. 2009;32(4):493-499. doi: 10.1007/s00449-008-0269-6

51. Apine OA, Jadhav JP. Fermentation of Cashew Apple (Anacardium Occidentale) Juice Into Wine by Different Saccharomyces Cerevisiae Strains: A Comparative Study. Biotechnology. 2015;4(3):6-10. https://www. worldwidejournals.com/paripex/recent_issues_ pdf/2015/March/March_2015_1427458365_82.pdf 52. Rodrigues THS, Dantas MAA, Pinto GAS, Goncalves LRB. Tannase production by solid state fermentation of cashew apple bagasse. Appl Biochem Biotechnol. 2007;137-140(1-12):675-688. doi: 10.1007/s12010007-9088-5

53. Prommajak T, Leksawasdi N, Rattanapanone N. Biotechnological valorization of cashew apple: A review. Chiang Mai Univ J Nat Sci. 2014;13(2):159-182. doi: 10.12982/CMUJNS.2014.0029

54. Sabu A, Pandey A, Jaafar Daud M, Szakacs G. Tamarind seed powder and palm kernel cake: Two novel agro residues for the production of tannase under solid state fermentation by Aspergillus niger ATCC 16620. Bioresour Technol. 2005;96(11):1223-1228. doi: 10.1016/j.biortech.2004.11.002

55. Banerjee D, Mondal KC, Pati BR. Tannase production by Aspergillus aculeatus DBF9 through solid-state fermentation. Acta Microbiol Immunol Hung. 2007;54(2):159-166. doi: 10.1556/amicr.54.2007.2.6

56. Kumar R, Sharma J, Singh R. Production of tannase from Aspergillus ruber under solid-state fermentation using jamun (Syzygium cumini) leaves. Microbiol Res. 2007;162(4):384-390. doi: 10.1016/j. micres.2006.06.012

57. Joseph ADO. Comparative Studies of Wine Produced By Spontaneous and Controlled Fermentation of Preserved Cashew (Anacardium Occidentale) Juice. Res J Biol Sci. 2010;5(7):460-464. doi: 10.3923/ rjbsci.2010.460.464

58. Neelakandan T, Usharani G, Nagar A. Optimization and production of bioethanol from cashew apple juice using immobilized yeast cells by Saccharomyces cerevisiae. Am J Sustain Agric. 2009;4(2):85-88.

59. Pinheiro ADT, Rocha MVP, MacEdo GR, Goncalves LRB. Evaluation of cashew apple juice for the production of fuel ethanol. Appl Biochem Biotechnol. 2008;148(13):227-234. doi: 10.1007/s12010-007-8118-7 